Finn Kenneth Hansen

\title{
De offentlige udgifters fordelingsmæssige virkninger
}

\begin{abstract}
Gennem de seneste 25-30 år har der været en tendens til, at skatternes og den offentlige sektors ydelser har haft en stadig mindre omfordelende rolle. I 1980'erne er billedet imidlertid ændret: Efter skattereformen fra 1987 betaler de højeste indkomstgrupper en større andel af de samlede imdkomstskatter. Den omfordelende effekt af de offentlige indkomstoverforsler er ogsȧ øget i 1980'erne, dog i vidt omfang fordi der er sket en forøgelse i antallet af langvarigt arbejdsløse.
\end{abstract}

\section{Diskussionen om den offentlige sektor}

Ikke på noget tidspunkt i udviklingen af den offentlige sektor har vi set en så omfattende debat om dens rolle, funktion og størrelse, som netop her i 1980'erne.

Hvor lighed og måske specielt en større økonomisk lighed end den markedskræfterne kan byde på, har haft og har en høj rang i de forventninger, som er associeret med den voksende og komplicerede velfærdsstat, er det i dag den offentlige sektors størrelse og effektivitet, der i langt højere grad er i fokus.

To helt aktuelle bidrag omkring den offentlige sektor (Budgetdepartementet, 1990; Forum for industriel udvikling, 1990) viser med al tydelighed denne tendens. Den offentlige sektors fordelingspolitiske rolle omtales i den ene rapport alene med fire linjer, hvor det hedder: „Også mere fordelingspolitiske hensyn kan dog spille ind ved vurderingen af de offentlige udgifter. Det gælder blandt andet, at de offentlige udgifter ikke alene kan påvirke incitamenterne på det private arbejdsmarked, men også influerer på den sociale stabilitet " (Budgetdepartementet, 1990). I den anden rapport omtales den offentlige sektors omfordelende rolle kun sporadisk. På baggrund af udbygningen af de offentlige ydelser til alle indkomstgrupper sættes der imidlertid spørgsmålstegn ved denne funktion. "De offentlige ydelser er i betydeligt omfang gjort uafhængig af indkomsten, ligesom forsørgerbegrebet næsten er forsvundet. Den offentlige sektor fremstår dermed i stigende grad som et service- og tryghedssystem for alle borgere snarere end som et omfordelingsystem « (Forum for industriel udvikling, 1990).

Den manglende interesse for at inddrage vurderinger af de fordelingsmæssige virkninger af det offentliges udgifts- og indtægtspolitik kan synes paradoksal, eftersom de fordelingsmæssige overvejelser og konsekvenser ofte spiller en væsentlig rolle ved udformningen og gennemførelsen af de fleste økonomisk-politiske foranstaltninger. Dette bekræftes næsten dagligt, når man ser den aktuelle diskussion af skattepolitikken og på den diskussion, som førtes op til gennemførelsen af skattereformen af 1987. Opmærksomheden om de fordelingspolitiske konsekvenser gælder måske ikke mindst det socialpolitiske område og gennemførelsen af de fleste ændringer af det offentliges indkomstoverførsler. 
Finn Kenneth Hansen

\title{
De offentlige udgifters fordelingsmæssige virkninger
}

\begin{abstract}
Gennem de seneste 25-30 år har der været en tendens til, at skatternes og den offentlige sektors ydelser har haft en stadig mindre omfordelende rolle. I 1980'erne er billedet imidlertid ændret: Efter skattereformen fra 1987 betaler de højeste indkomstgrupper en større andel af de samlede imdkomstskatter. Den omfordelende effekt af de offentlige indkomstoverforsler er ogsȧ øget i 1980'erne, dog i vidt omfang fordi der er sket en forøgelse i antallet af langvarigt arbejdsløse.
\end{abstract}

\section{Diskussionen om den offentlige sektor}

Ikke på noget tidspunkt i udviklingen af den offentlige sektor har vi set en så omfattende debat om dens rolle, funktion og størrelse, som netop her i 1980'erne.

Hvor lighed og måske specielt en større økonomisk lighed end den markedskræfterne kan byde på, har haft og har en høj rang i de forventninger, som er associeret med den voksende og komplicerede velfærdsstat, er det i dag den offentlige sektors størrelse og effektivitet, der i langt højere grad er i fokus.

To helt aktuelle bidrag omkring den offentlige sektor (Budgetdepartementet, 1990; Forum for industriel udvikling, 1990) viser med al tydelighed denne tendens. Den offentlige sektors fordelingspolitiske rolle omtales i den ene rapport alene med fire linjer, hvor det hedder: „Også mere fordelingspolitiske hensyn kan dog spille ind ved vurderingen af de offentlige udgifter. Det gælder blandt andet, at de offentlige udgifter ikke alene kan påvirke incitamenterne på det private arbejdsmarked, men også influerer på den sociale stabilitet " (Budgetdepartementet, 1990). I den anden rapport omtales den offentlige sektors omfordelende rolle kun sporadisk. På baggrund af udbygningen af de offentlige ydelser til alle indkomstgrupper sættes der imidlertid spørgsmålstegn ved denne funktion. "De offentlige ydelser er i betydeligt omfang gjort uafhængig af indkomsten, ligesom forsørgerbegrebet næsten er forsvundet. Den offentlige sektor fremstår dermed i stigende grad som et service- og tryghedssystem for alle borgere snarere end som et omfordelingsystem « (Forum for industriel udvikling, 1990).

Den manglende interesse for at inddrage vurderinger af de fordelingsmæssige virkninger af det offentliges udgifts- og indtægtspolitik kan synes paradoksal, eftersom de fordelingsmæssige overvejelser og konsekvenser ofte spiller en væsentlig rolle ved udformningen og gennemførelsen af de fleste økonomisk-politiske foranstaltninger. Dette bekræftes næsten dagligt, når man ser den aktuelle diskussion af skattepolitikken og på den diskussion, som førtes op til gennemførelsen af skattereformen af 1987. Opmærksomheden om de fordelingspolitiske konsekvenser gælder måske ikke mindst det socialpolitiske område og gennemførelsen af de fleste ændringer af det offentliges indkomstoverførsler. 
Der har i Danmark - til forskel fra andre lande vi normalt sammenligner os med - været en lang tradition for at vurdere den offentlige sektors samlede omfordelende rolle og vurderinger af henholdsvis skatternes og indkomstoverførslernes bidrag til denne omfordeling. For indkomståret 1938/39 foretog Viggo Kampmann og P. Bjørn Olsen en undersøgelse. For indkomståret 1949 foreligger Niels Ussings undersøgelse. For indkomsåret 1955 foreligger en undersøgelse af Keld Bjerke, og for indkomståret 1963 foretog Det Økonomiske Råd en undersøgelse. Derudover findes der en skønsmæssig opgørelse for året 1970 af Mogens Lykketoft (Hansen, 1981). Der har imidlertid været meget lidt forskning omkring de fordelingsmæssige virkninger af det offentliges enkeltforanstaltninger. Det gælder såvel indkomstoverførsler som serviceydelser (Albæk og Christiansen, 1987).

Dette er blandt andet en af grundene til at de fordelingpolitiske overvejelser af det offentliges udgifter og indtægter ikke på samme måde som for eksempel de budgetmæssige og beskæftigelsesmæssige virkninger har indgået som et mere integreret element $i$ vurderingen af de enkelte offentlige foranstaltninger. Etableringen af Økonomiministeriets lovmodel er imidlertid et væsentligt fremskridt. Mulighederne for at inddrage fordelingspolitiske overvejelser er gode, idet man med lovmodellen har et modelapparat, som kan vurdere de fordelingsmæssige virkninger af stort set alle offentlige udgifter og indtægter.

Man må imidlertid konstatere, at de fordelingspolitiske overvejelser vedrørende det offentliges aktiviteter har haft og åbenbart stadig har en lidet fremtrædende rolle både $\mathrm{i}$ forskningen og $\mathrm{i}$ den offentlige diskussion om den offentlige sektor.

Dette kan hænge sammen med tilliden til den offentlige sektors karakter og struktur og omstændighederne ved ekspansionen af den offentlige sektor. Selv om der har været en kraftig forøgelse af den offentlige sektors aktiviteter $\mathrm{i}$ løbet af de sidste 25-30 år, har den grundlæggende struktur for den offentlige sektor ofte benævnt som "den skandinaviske model - stort set været uforandret. Tilliden til, at denne model virker omfordelende til fordel for samfundets svagest stillede, kan være en af forklaringerne på, at de fordelingsmæssige og omfordelende virkninger mere eller mindre er blevet taget for givne.

Dertil kan man føje, at de fordelingspolitiske muligheder i den periode, hvor den offentlige sektor ekspanderede langt stærkere end andre sektorer, har været gunstige og uproblematiske, fordi den samtidige kraftige økonomisk vækst, gjorde det muligt at iværksætte velfærdsfremmende foranstaltninger, som stort set alle befolkningsgrupper kunne fả del i.

\section{De fordelingspolitiske problemer}

Set i bakspejlet er der væsentlige grunde til at beskæftige sig med fordelingsvirkningerne af det offentliges foranstaltninger. De mange undersøgelser af den offentlige sektors omfordelende rolle igennem tiden viser ganske vist, at der $\mathrm{i}$ hele efterkrigstiden har været tale om en klar omfordeling. Men ser vi på de komponenter, som har bidraget til denne omfordeling, har der været en klar tendens gennem de sidste 25-30 år til, at skatternes omfordelende rolle er blevet mindre 
og mindre, og at omfordelingen ved starten af 1980'erne stort set kun foregår via de offentlige indkomstoverførsler (Hansen, 1985; Sørensen, 1989).

I slutningen af 1970'erne kom pensioner, boligsikring og bistandsydelser helt klart de allernederste indkomstgrupper til gode. Dagpengene kommer fortrinsvis mellemindkomstgrupperne til gode, mens det helt markant ikke er de nederste indkomstgrupper, der nyder godt af familierettede overførsler som børnetilskud og barselspenge (Hansen, 1985).

Ser vi på de fordelingsmæssige virkninger af nogle af de væsentligste serviceydelser i samme periode, er der store forskelle. Serviceydelser på ældreområdet kommer klart de nederste indkomstgrupper til gode, mens serviceydelser inden for sundhedssektoren stort set kommer alle indkomstgrupper lige meget til gode. Serviceydelser inden for uddannelse og børneområdet kommer derimod mest de øverste indkomstgrupper til gode (Hansen, 1985).

Sammenligner man de samlede indkomstoverførsler med de samlede serviceydelser, viser det sig således, at indkomstoverførslerne i langt større udstrækning kommer de laveste indkomstgrupper til gode end de offentlige serviceydelser. I slutningen af 1970'erne medførte stigningen i skattetrykket, at de laveste indkomstgrupper betalte en større og større andel af de samlede skatter og afgifter, mens fordelingsvirkningerne af de offentlige indkomstoverførsler og serviceydelser, trods ændringer i lovgivning for nogle af ydelserne, ikke ændrede sig markant.

Spørgsmålet er imidlertid, om denne tendens i fordelingspolitikken har ændret sig i løbet af 1980'erne. Dette spørgsmål er ikke alene interessant pả baggrund af de ændringer, der er sket i forbindelse med skattereformen og de lovændringer, der har fundet sted af indkomstoverførslerne, som for eksempel reguleringen af de fleste indkomstoverførsler, ændringer på børnetilskudsområdet og kontanthjælpsområdet, men også på baggrund af de ændringer, som har fundet sted i det almindelige fordelingsbillede.

De fordelingspolitiske virkninger er ikke alene afhængige af udformningen af de enkelte foranstaltninger for eksempel for indkomstoverforslernes tildelingsog udmålingskriterier og ændringer i disse, men også af, hvordan det generelle fordelingsbillede og fordelingsproblemerne udvikler sig.

Fordelingsproblemerne synes i 1980'erne at være skærpet på grund af den lavere vækst og de forværrede økonomiske balanceproblemer. Igennem de sidste tyve ăr har der været en forsat stigning i den andel af befolkningen, som er offentligt forsørget og som har været det $\mathrm{i}$ længere tid. Med den forsat store arbejdsløshed og udstødningen fra arbejdsmarkedet er der et stigende antal personer og familier, som bliver whængende $\mathbf{i}$ dagpengesystemet eller bistandssystemet og altså over en længere årrække er på midlertidige indkomstoverførsler (Social rapport, 1989 og 1990). Derudover er en større del overgået til varige ydelser, så som førtidspension. Det er ikke mindst denne udvikling, som har medfort en mere omfattende diskussion om passive ydelser og aktive foranstaltninger og samtidig været baggrunden for en stigende interesse for fattigdomsproblematikken i 1980'erne.

Hvor der i 1960'erne og 1970'erne blev sat fokus på den ulige fordeling af goderne mellem forskellige befolkningsgrupper i samfundet, tales der her i 1980'er- 
ne om insider-outsider problemet, opdeling af befolkningen i A- og B-hold, totredjedelssamfund mm.

Benævnelserne er udtryk for en ændring af fordelingsbilledet, hvor det store flertal trods forskelle $i$ indkomster og levekår klart adskiller sig fra et stort mindretal, som i udpræget grad er afhængige af offentlige indkomstoverførsler, og hvor stigningen i deres indkomster er afhængig af politiske afgørelser.

Denne udvikling påvirker ikke alene omfanget af offentlige ydelser - og specielt omfanget af indkomstoverførsler - men også de fordelingsmæssige virkninger af ydelserne. I en fordelingspolitisk betragtning kunne det således være hensigtsmæssigt at skelne mellem fordelingsvirkninger, som har en aktiv fordelingspolitisk karakter, og fordelingsvirkninger, som i højere grad er afledt af ændringer i samfundsudviklingen. Ved vurderingen af for eksempel ændringer i de enkelte indkomstoverførslers fordelingsvirkninger kunne det således være væsentligt at sondre mellem virkninger, som har sin baggrund i direkte lovændringer i tildelings- og udmålingskriterierne, og virkninger, som har sin baggrund i ændringer $i$ antallet og sammensætningen af modtagerne af den konkrete ydelse.

\section{Fordelingsanalyser af den offentlige sektors ydelser}

Som omtalt er der i Danmark en lang tradition for at se på omfordelingen via den offentlige sektor. Oftest undersøges omfordelingen via den offentlige sektor ved størrelsen af de ressourcer, der via det offentlige flyttes fra den bedst stillede del af befolkningen til den dårligst stillede del af befolkningen. Forskellige undersøgelser gennem tiden har som regel undersøgt et enkelt år, og det er derfor vanskeligt direkte at sammenlige omfordelingsresultaterne igennem perioden. Da undersøgelserne helt frem til $1963 \mathrm{i}$ vidt omfang alene omfatter de direkte skatter og indkomstoverforsler, er det kun muligt at foretage en mere langsigtet vurdering af disse to komponenters bidrag til omfordelingen. Først med anvendelse af Danmarks Statistiks forbrugsundersøgelse har det været muligt også at inddrage de indirekte skatter og det offentliges serviceydelser i det offentliges samlede omfordeling (Hansen, 1981, 1985).

Først med Socialforskningsinstituttets undersøgelse Fordelingspolitikken og dens virkninger er der foretaget en mere samlet belysning af de enkelte indkomstoverførslers og enkelte serviceydelsers fordelings- og omfordelingvirkininger for årene 1976 og 1981 (Hansen, 1985). Undersøgelsen omfatter alle husstande, hvori indgår mindst en person i alderen 20-69 år. Analyseenheden er således personer, men personer karakteriseret ved deres familiemæssige (husstandsmæssige) forhold, som for eksempel husstandens samlede indkomst. Fordelings- og omfordelingsvirkninger af de enkelte ydelser ses forst og fremmest i relation til en bruttoindkomstfordeling, hvor husstandenes indkomster er opdelt efter størrelse i tiendedele (decilgrupper). En indkomstrelateret fordelings- og omfordelingsanalyse kan have sine fordele specielt i vurderingen af omfordelingsvirkningerne, hvor fordelingen af den enkelte ydelse på indkomstgrupper sammenholdes med fordelingen af skatterne. Ulempen ved en sådan tilgangsvinkel er imidlertid, at alle ydelser uafhængigt af deres forskellige formål sammenholdes med en og samme bruttoindkomstfordeling. 
Det offentliges forskellige indkomstoverforsler og serviceydelser er i væsentligt omfang relateret til bestemte faser i den enkelte persons eller families livsforløb. Derfor ville en fordelingspolitisk analyse i højere grad skulle foretages i relation til en livsfaseinddeling af personer og familier. En sådan livsfaserelateret fordelings- og omfordelingsanalyse er det muligt at foretage med udgangspunkt i Socialforskningsinstituttets undersøgelse, af Bornefamiliernes økonomiske forhold (Hansen, 1990a). I denne undersøgelse er personer og familier inddelt efter deres livsfasesituation i henholdsvis børnefamilier underopdelt efter yngste barns alder og familier uden børn underopdelt på aldersgrupper.

Tabel 1. Andel af direkte indkomstskatter for de fem nederste indkomstgrupper samt skatteandel i forhold til familieandel. 1984-1988

\begin{tabular}{|c|c|c|c|c|c|c|}
\hline & \multicolumn{3}{|c|}{$\begin{array}{l}\text { Skatteandel for de fem } \\
\text { nederste indkomst- } \\
\text { grupper }{ }^{1} \mathrm{i} \text { pct. }\end{array}$} & \multicolumn{2}{|c|}{$\begin{array}{l}\text { Skatteandel i } \\
\text { forhold til } \\
\text { familieandel }^{2}\end{array}$} & \multirow{2}{*}{$\begin{array}{c}\begin{array}{c}\text { En- } \\
\text { dring }\end{array} \\
1984- \\
1988\end{array}$} \\
\hline & 1984 & 1986 & 1988 & 1984 & 1988 & \\
\hline \multicolumn{7}{|c|}{ Smäbrrnsfamilier: } \\
\hline Par & 40 & 40 & 38 & $+4,8$ & $+5,2$ & $+0,4$ \\
\hline Enlige & 30 & 31 & 30 & $-0,7$ & $-0,8$ & $-0,1$ \\
\hline \multicolumn{7}{|c|}{ Skolebornsfamilier: } \\
\hline Par & 37 & 38 & 37 & $+9,3$ & $+9,7$ & $+0,3$ \\
\hline Enlige & 33 & 33 & 31 & $-0,6$ & $-0,6$ & - \\
\hline \multicolumn{7}{|c|}{ Voksenbornsfamilier: } \\
\hline Par & 36 & 37 & 36 & $+3,6$ & $+3,6$ & - \\
\hline Enlige & 33 & 34 & 33 & $+0,2$ & $+0,2$ & - \\
\hline \multicolumn{7}{|c|}{$\begin{array}{l}\text { Familier uden born: } \\
20-49 \text { ar: }\end{array}$} \\
\hline Par & 37 & 37 & 35 & $+3,5$ & $+4,3$ & $+0,7$ \\
\hline Enlige & 25 & 24 & 23 & $-6,6$ & $-7,5$ & $-0,9$ \\
\hline \multicolumn{7}{|l|}{ 50-66 ar: } \\
\hline Par & 27 & 27 & 26 & $+2,7$ & $+2,2$ & $-0,3$ \\
\hline Enlige & 18 & 20 & 19 & $-3,2$ & $-3,3$ & $-0,1$ \\
\hline \multicolumn{7}{|c|}{67 ar og derover: } \\
\hline Par & 22 & 21 & 22 & $-1,8$ & $-1,9$ & $-0,1$ \\
\hline Enlige & 6 & 6 & 9 & $-11,1$ & $-11,2$ & $-0,1$ \\
\hline
\end{tabular}

Kilde: Egne beregninger foretaget pả materiale fra Socialforskningsinstituttets rapport: Bornefamiliernes okonomi (Hansen, 1990a).

1 De fem nederste indkomstgrupper i den disponible indkomstfordeling.

+ angiver de procentpoint skatteandelen er storre end familieandelen.

- angiver de procentpoint skatteandelen er mindre end familieandelen.

Familieandelen fremgär af Bilagstabel 1 side 469. 
Med udgangspunkt i dette materiale vil jeg i det følgende rette blikket mod to centrale hovedproblemstillinger. Den ene er, hvordan fordelingsvirkningerne af de direkte indkomstskatter har udviklet sig i 1980'erne og specielt, hvad skattereformen af 1987 har betydet. Den anden er fordelingsvirkningerne af det offentliges indkomstoverførsler, herunder specielt fordelingsvirkningerne af arbejdsløshedsdagpengene og børnetilskuddene.

\section{De direkte skatters fordelingsmæssige virkninger}

Fordelingsvirkningerne af de direkte indkomstskatter viste for perioden 1976 til 1981, at de laveste indkomstgrupper (den nederste halvdel i bruttoindkomstfordelingen) betalte en stigende andel af de samlede indkomstskatter. Fra i 1976 at have betalt 29 pct. af de samlede indkomstskatter betalte de i 198134 pct. Først med skattereformen i 1987 sker der ændringer i den personlige beskatning, og alt tyder på, at de laveste indkomstgrupper frem til da betaler en svagt stigende andel af de samlede indkomstskatter jf. tabel 1.

1987-reformen indebærer blandt andet en proportionalbeskatning på 50 pct. og indførelse af 6 pct.- og 12 pct.-skatten, en ændring af fradragene, så skatteværdien stort set er ens for alle, samt bortfald af visse fradrag og en forøgelse af personfradraget. Dertil kommer som en del af skattereformen den skattefri børnefamilieydelse.

I hidtidige vurderinger af skattereformens fordelingsmæssige virkninger indgår alle disse elementer (Finansministeriet, 1985). Năr der i det følgende ses på de direkte skatters fordelingsvirkninger, vil der imidlertid blive set bort fra børnefamilieydelsen, der er en indkomstoverførsel.

Med skattereformen ændres de direkte skatters fordelingsvirkninger, jf. tabel 1 . For alle familiegrupper (borset fra enlige pensionister) er der et fald i skatteandelen for de laveste indkomstgrupper og dermed en stigning for de øverste indkomstgrupper. Med skattereformen ser det således ud til, at den forudgående tendens, at de laveste indkomstgrupper betaler en stigende andel af de samlede indkomstskatter, er stoppet, og at de øverste indkomstgrupper betaler en lidt større andel end før skattereformen. Ændringen er dog så lille, at den langt fra kan opveje den igennem mange år stigende andel for de laveste indkomstgrupper.

For stort set alle børnefamilier gælder det, at de laveste indkomstgrupper (den nederste halvdel) blandt parrene betaler lidt over en tredjedel af de samlede indkomstskatter, hvilket også gælder for par i alderen 20-49 år uden børn, mens de enlige betaler lidt under en tredjedel.

For udviklingen i skatteandelen mellem de forskellige familiegrupper er det karakteristisk, at parbørnefamilierne og barnløse par i alderen 20-49 år betaler en lidt større skatteandel i 1988 end i 1984, mens stort set alle enlige og barnløse par $i$ alderen 50 år og derover betaler en lidt mindre andel. Denne ændring skyldes formodentlig, at der er en langt større ejerandel blandt børnefamilierne og par uden børn end blandt de øvrige familiegrupper.

Jeg kan således konkludere, at fordelingsvirkningerne af de direkte skatter er blevet ændret med skattereformen, og at de højere indkomstgrupper og boligejerne - specielt på grund af ændringerne i værdien af skattefradragene - har måt- 
tet betale en større andel af de direkte skatter. Dermed er tendensen til, at de laveste indkomstgrupper betaler en stigende andel af indkomstskatterne, stoppet.

\section{De fordelingsmassige virkninger af indkomstoverforslerne}

I løbet af 1980'erne har der været en meget stor stigning i det offentliges indkomstoverførsler. Dette skyldes dels, at flere personer er blevet omfattet af overførslerne for eksempel førtidspensionister og børnefamilier, dels stigningen i ydelser til børnefamilierne, den forbedrede uddannelsesstøtte og endelig stigningen i antallet af arbejdsløse og antallet af bistandsmodtagere.

Hvordan er det gảet med de fordelingsmæssige virkninger af de samlede indkomstoverførsler, som i 1988 var i størrelsesordenen 120 mia. kr.?

For perioden 1976 til 1981, var der til forskel fra udviklingen på skattesiden ingen ændringer i fordelingsvirkningerne. 72 pct. af de samlede indkomstoverførsler tilfaldt de laveste indkomstgrupper (den nederste halvdel) både i 1976 og i 1981.

I perioden 1976-81 indskrænkedes kredsen af personer, som modtog indkomstoverførsler. Det galder på børnetilskudsområdet med indførelsen af indkomstgradueringen og med stramninger i adgangen til arbejdsløhedsdagpenge. Derudover var der forringelser af indkomstoverførslerne i form af direkte reduceringer eller suspension af regulering af ydelserne, for eksempel hvad angår børnetilskud, syge- og arbejdsløshedsdagpenge. Endelig indførtes socialindkomsten, som bevirkede, at flere ydelser udbetaltes efter andre kriterier end hidtil, og betød bortfald for nogle befolkningsgrupper (Liebetrau, 1983).

For perioden 1984 til 1988 er der inden for de fleste familiegrupper - bortset fra småbørns- og skolebørnsfamilierne - tale om en relativ stor stigning $i$ andelen af indkomstoverførslerne for de laveste indkomstgrupper (den nederste halvdel). For par uden børn stiger andelen således fra 72 pct. til 76 pct., mens den for enlige stiger fra 70 pct. til 75 pct. Inden for småbørns- og skolebørnsfamilierne er der stort set tale om en uændret andel for de laveste indkomstgrupper (se tabel 2).

Mellem de forskellige familiegrupper opdelt efter livsfasesituation viser det sig, at småbørns- og skolebørnsfamilierne modtager en større andel af de samlede indkomstoverførsler i 1988 end i 1984, mens alle andre grupper modtager en mindre andel. Dette skyldes formentlig indførelsen af børnefamilieydelsen til alle børn under 18 år.

Netop på grund af livsfaseopdelingen af familierne er det interessant at opholde sig lidt ved indkomstoverforslernes fordelingsvirkninger inden for de enkelte familiegrupper. Andelen for den nederste halvdel viser sig således at være større for parrene end for enlige blandt samtlige familiegrupper. Derudover viser det sig, at andelen for den nederste halvdel er større for familier i aldersintervallet 20-66 år uden børn end for børnefamilierne. Endelig viser det sig ikke overraskende, at indkomstoverførslerne blandt pensionisterne falder mere jævnt på indkomstgrupperne end blandt de øvrige familiegrupper. I forhold til deres andel af befolkningen modtager pensionisterne en større andel af de samlede indkomstoverførsler. Det samme er tilfældet for par uden børn i alderen 50-66 år. Af familiegrupper, der modtager en meget lavere andel, end de udgør af befolknin- 
Tabel 2. Andel af offentlige indkomstoverforsler for de fem nederste indkomstgrupper samt andel af offentlige indkomstoverførsler i forhold til familieandel. 1984-1988

\begin{tabular}{|c|c|c|c|c|c|}
\hline & \multicolumn{2}{|c|}{$\begin{array}{l}\text { Andel af ind- } \\
\text { komstoverførsler } \\
\text { for de fem } \\
\text { nederste indkomst- } \\
\text { grupper }{ }^{1} \mathrm{i} \text { pct. }\end{array}$} & \multicolumn{2}{|c|}{$\begin{array}{l}\text { Andel af ind- } \\
\text { komstoverforsler } \\
\text { i forhold til } \\
\text { familieandel }^{2}\end{array}$} & \multirow{2}{*}{$\begin{array}{c}\begin{array}{c}\text { En- } \\
\text { dring }\end{array} \\
1984- \\
1988 \\
\end{array}$} \\
\hline & 1984 & 1988 & 1984 & 1988 & \\
\hline \multicolumn{6}{|c|}{ Smábornsfamilier: } \\
\hline Par & 68 & 67 & $-1,0$ & $+0,7$ & $+1,7$ \\
\hline Enlige & 57 & 56 & $+0,4$ & $+0,7$ & $+0,3$ \\
\hline \multicolumn{6}{|c|}{ Skolebornsfamilier: } \\
\hline Par & 64 & 64 & $-5,3$ & $-3,8$ & $+1,5$ \\
\hline Enlige & 62 & 63 & $-0,1$ & $+0,1$ & $+0,2$ \\
\hline \multicolumn{6}{|c|}{ Voksenbornsfamilier: } \\
\hline Par & 62 & 65 & $-0,3$ & $-0,5$ & $-0,2$ \\
\hline Enlige & 59 & 63 & 0,0 & $-0,1$ & $-0,1$ \\
\hline \multicolumn{6}{|c|}{$\begin{array}{l}\text { Familier uden bern: } \\
20-49 \text { arr: }\end{array}$} \\
\hline Par & 72 & 76 & $-2,0$ & $-3,2$ & $-1,2$ \\
\hline Enlige & 70 & 75 & $-7,9$ & $-9,5$ & $-1,6$ \\
\hline \multicolumn{6}{|l|}{$50-66$ dr: } \\
\hline Par & 65 & 70 & $+5,8$ & $+5,1$ & $-0,7$ \\
\hline Enlige & 63 & 68 & $+0,5$ & $+0,4$ & $-0,1$ \\
\hline \multicolumn{6}{|c|}{67 ar og derover: } \\
\hline Par & 52 & 53 & $+7,4$ & $+7,3$ & $-0,1$ \\
\hline Enlige & 45 & 45 & $+2,5$ & $+2,6$ & $+0,1$ \\
\hline
\end{tabular}

Kilde: Egne beregninger foretaget pả materiale fra Socialforskningsinstituttets rapport: Bernefamiliernes økonomi (Hansen, 1990a).

1 De fem nederste indkomstgrupper i den disponible indkomstfordeling.

$2+$ angiver de procentpoint andelen af indkomstoverforsler er større end familieandelen.

- angiver de procentpoint andelen af indkomstoverførsler er mindre end familieandelen.

Familieandelen fremgår af Bilagstabel 1 side 469 .

gen, ser vi, at det især er parskolebørnsfamilier og barnløse par og enlige i alderen 20-49 år.

For en nærmere analyse af fordelingsvirkninger for de samlede indkomstoverførsler vil jeg i det følgende se nærmere på fordelingsvirkningerne for henholdsvis arbejdsløshedsdagpengene og familieydelserne, hvor sidstnævnte omfatter børnetilskud og boligsikring. Når der netop skal fokuseres på disse indkomstoverførsler, skyldes det den aktuelle diskussion omkring en dagpengereform samt for familieydelsernes vedkommende den ændring, der er sket på børnetilskudsområdet med indførelsen af en generel børnefamilieydelse. 


\section{Fordelingsvirkningerne af arbejdsløshedsdagpengene}

Igennem hele 1980'erne har antallet af arbejdsløse været markant højere end i 1970'erne. Det gælder både i antallet af registrerede arbejdsløse, antallet af personer, der har været berørt af arbejdsløshed og i antallet af personer med mere end 6 måneders arbejdsløshed inden for et år. Samtidig viser det sig, at antallet af langvarigt arbejdsløse - dvs. personer som har været arbejdsløse over halvdelen af en 6-årsperiode - har været stigende gennem 1980'erne (Hansen, 1990b). Realværdien i maksimumsdagpengebelølbet har været faldende frem til 1987, hvorefter der sker et lille løft i 1988.

Hvordan er det på denne baggrund gảet med fordelingsvirkningerne af arbejdsløshedsdagpengene? Grundet en forskellig angrebsvinkel i undersøgelsen for perioden 1976 til 1981 kan fordelingsvirkningerne af arbejdsløshedsdagpengene ikke direkte sammenholdes med fordelingsvirkningerne set i relation til en

Tabel 3. Andel af arbejdsløshedsdagpenge for de fem nederste indkomstgrupper samt andel af arbejdsløshedsdagpenge i forhold til familieandel. 1984-1988

\begin{tabular}{|c|c|c|c|c|c|}
\hline & \multicolumn{2}{|c|}{$\begin{array}{l}\text { Andel af A- } \\
\text { dagpenge for de } \\
\text { fem nederste } \\
\text { indkomst- } \\
\text { grupper' i pct. }\end{array}$} & \multicolumn{2}{|c|}{$\begin{array}{l}\text { Andel af A-dag- } \\
\text { penge i forhold } \\
\text { til familieandel }{ }^{2}\end{array}$} & \multirow{2}{*}{$\begin{array}{l}\text { En- } \\
\text { dring }\end{array}$} \\
\hline & 1984 & 1988 & 1984 & 1988 & \\
\hline \multicolumn{6}{|c|}{ Smäbornsfamilier: } \\
\hline Par & 68 & 72 & $+9,0$ & $+8,5$ & $-0,5$ \\
\hline Enlige & 56 & 59 & $+0,4$ & $+0,8$ & $+0,4$ \\
\hline \multicolumn{6}{|c|}{ Skolebornsfamilier: } \\
\hline Par & 62 & 68 & $-0,9$ & $-0,6$ & $+0,3$ \\
\hline Enlige & 66 & 71 & $-0,7$ & $-0,5$ & $+0,2$ \\
\hline \multicolumn{6}{|c|}{ Voksenbornsfamilier: } \\
\hline $\mathrm{Par}$ & 52 & 57 & $+1,4$ & $+1,3$ & $-0,1$ \\
\hline Enlige & 47 & 53 & $+0,1$ & $+0,1$ & - \\
\hline \multicolumn{6}{|c|}{$\begin{array}{l}\text { Familier uden born: } \\
20-49 \text { âr: }\end{array}$} \\
\hline Par & 63 & 68 & $+4,2$ & $+3,2$ & $-1,0$ \\
\hline Enlige & 61 & 67 & $-3,6$ & $-5,4$ & $-1,8$ \\
\hline \multicolumn{6}{|l|}{$50-66$ ar: } \\
\hline Par & 34 & 38 & $-4,5$ & $-2,7$ & $+1,8$ \\
\hline Enlige & 48 & 52 & $-5,4$ & $-4,8$ & $+0,6$ \\
\hline
\end{tabular}

Kilde: Egne beregninger foretaget på materiale fra Socialforskningsinstituttets rapport: Bornefa. miliernes okonomi (Hansen, 1990a).

1 De fem nederste indkomstgrupper i den disponible indkomstfordeling.

$2+$ angiver de procentpoint andelen af A-dagpenge er storre end familieandelen.

- angiver de procentpoint andelen af A-dagpenge er mindre end familieandelen.

Familieandelen fremgär af Bilagstabel 1 side 469 . 
livsfasesynsvinkel. Derimod er det muligt at sammenholde tendenserne i udviklingen. Set i relation til bruttoindkomstfordelingen modtog den nederste halvdel i 197646 pct. af dagpengene og i 198154 pct. I denne periode var der således tale om en klar ændring til fordel for de laveste indkomstgrupper.

I relation til livsfasegruppen fremgår det af tabel 3, at arbejdsløshedsdagpengene inden for de forskellige familiegrupper i langt større omfang modtages af de laveste indkomstgrupper. For parsmåbørnsfamilierne, skolebørnsfamilierne og familier uden børn i alderen 20-49 år er det således over totredjedel af dagpengene, som tilfalder den nederste halvdel. For par i alderen 50-66 år uden børn modtager de laveste indkomstgrupper kun lidt over en tredjedel, hvilket skyldes, at de laveste indkomstgrupper stort set omfatter efterlønsmodtagere og førtidspensionister, mens de erhvervsaktive er placeret i den øverste halvdel af indkomstfordelingen.

Inden for alle familiegrupper modtager den nederste halvdel i 1988 en større andel af arbejdsløshedsdagpengene end i 1984. Altsả stort set samme tendens som for perioden 1976 til 1981. De laveste indkomstgrupper modtager en større og større andel af de samlede arbejdsløshedsdagpenge.

Mellem familiegrupperne er der stort set ikke sket nogen ændringer i perioden. Det er dog værd at bemærke, at specielt småbørnsfamilierne i forhold til deres andel af befolkningen modtager en relativ stor andel af arbejdsløshedsdagpengene.

På trods af, at antallet af arbejdsløse er stigende i perioden 1976-81 og faldende i perioden 1984-88 - ganske vist på et højere niveau - ser vi, at fordelingsvirkningerne af arbejdsløshedsdagpengene viser samme tendens: De laveste indkomstgrupper modtager en større og større andel af de samlede dagpenge. Når dette er tilfældet, kan det skyldes, at der i perioden 1984-88 i højere grad er tale om en stigning $i$ den langvarige arbejdsløshed end en stigning $i$ antallet af arbejdsløse.

\section{Fordelingsvirkningerne af familieydelserne}

Selv om familieydelserne både omfatter boligydelse og børnetilskud, er det specielt ændringerne på børnetilskudsområdet i 1987, som påkalder sig en fordelingspolitisk interesse. Fra at udviklingen på børnetilskudsområdet frem til 1984 var karakteriseret ved, at færre og færre børnefamilier modtog børnetilskud, og, at realværdien af børnetilskuddene faldt, er situationen fra 1987, at alle børnefamilier med børn under 18 år modtager en børnefamilieydelse, som i niveau ligger klart over det almindelige børnetilskud (Knudsen, 1987).

Disse ændringer har påvirket de fordelingsmæssige virkninger af familieydelserne. Som det fremgår af tabel 4, har det især påvirket fordelingsvirkningerne inden for parbørnefamilierne. Hvor over 60 pct. af børnetilskuddene i 1986 gik til de laveste indkomstgrupper, er der i 1988 tale om en stort set ligelig fordeling. Derimod har ændringer ikke haft så stor betydning for de enlige børnefamilier.

Ser vi på fordelingen mellem børnefamilierne af det langt større beløb til familieydelser i 1988 sammenlignet med årene tidligere, fremgår det da også, at det er parfamilierne, som har fảet en større andel i dette større beløb. I forhold til deres andel af børnefamilierne er det dog forsat således, at de enlige børnefamilier modtager en langt større andel af de samlede familieydelser. 
Tabel 4. Andel af familieydelser for de fem nederste indkomstgrupper samt andel af familieydelser i forhold til familieandel. 1984-1988

\begin{tabular}{|c|c|c|c|c|c|c|}
\hline & \multicolumn{3}{|c|}{$\begin{array}{l}\text { Andel af familieydelser for } \\
\text { de fem nederste indkomst- } \\
\text { grupper }{ }^{2} \mathrm{i} \text { pct. }\end{array}$} & \multicolumn{2}{|c|}{$\begin{array}{l}\text { Andel af familie- } \\
\text { ydelser i forhold } \\
\text { til familieandel }{ }^{2}\end{array}$} & \multirow{2}{*}{$\begin{array}{c}\begin{array}{c}\text { En- } \\
\text { dring }\end{array} \\
1984- \\
1988 \\
\end{array}$} \\
\hline & 1984 & 1986 & 1988 & 1984 & 1988 & \\
\hline \multicolumn{7}{|c|}{ Smäbornsfamilier: } \\
\hline Par & 61 & 63 & 50 & $-7,9$ & $-5,6$ & $+2,3$ \\
\hline Enlige & 44 & 44 & 42 & $+8,1$ & $+6,2$ & $-1,9$ \\
\hline \multicolumn{7}{|c|}{ Skolebornsfamilier: } \\
\hline Par & 63 & 65 & 51 & $-13,9$ & $-8,6$ & $+5,3$ \\
\hline Enlige & 53 & 55 & 52 & $+13,7$ & $+8,0$ & $-5,7$ \\
\hline
\end{tabular}

Kilde: Egne beregninger foretaget på materiale fra Socialforskningsinstituttets rapport: Bornefamiliernes okonomi (Hansen, 1990a).

1 De fem nederste indkomstgrupper i den disponible indkomstfordeling.

2 + angiver de procentpoint andelen af familieydelser er støre end familieandelen.

- angiver de procentpoint andelen af familieydelser er mindre end familieandelen.

Familieandelen fremgår af Bilagstabel 1 side 469.

Det kan konstateres, at fordelingsvirkningerne af familieydelserne er ændret markant i forhold til parbørnefamilierne. Hvor børnetilskuddene før overvejende gik til de laveste indkomstgrupper, er de nu ligeligt fordelt pả sảvel lav- som højindkomstgrupperne.

\section{Fordelingspolitikken i 1980'erne}

På trods af en lavere økonomisk vækst og forværrede balanceproblemer i 1980 'erne viser fordelingsvirkningerne af væsentlige dele af det offentliges udgifter og indtægter en positiv udvikling. Hvad angår de direkte indkomstskatter ser det ud til, at tendensen til, at de lavere indkomstgrupper betaler en større og større andel af de direkte skatter, er stoppet. Med skattereformen af 1987 har de øverste indkomstgrupper måttet betale en lidt større andel af de direkte skatter.

Hvad angår det offentliges indkomstoverførsler er der i perioden 1984 til 1988 sket en lidt større overførsel til småbørns- og skolebørnsfamilierne og til enlige folkepensionister, men inden for de enkelte familiegrupper modtager de laveste indkomstgrupper en større andel af indkomstoverførsler i 1988 end i 1984 . Dette på trods af, at en af de væsentligste ændringer i fordelingspolitikken, nemlig på børnetilskudsområdet, er gået i retning af at fordele indkomstoverførslerne til både høj- og lavindkomst børnefamilier.

Når der alligevel har været tale om positiv udvikling i fordelingsvirkningerne af de offentlige indkomstoverførsler, skyldes det nok så meget den ændring, der er sket i fordelingsbilledet i løbet af 1980'erne. Den positive udvikling i fordelingsvirkningerne skal $\mathrm{i}$ høj grad ses på baggrund af en forværret udvikling $\mathrm{i}$ antallet af længerevarende arbejdsløse.

Sammenlignet med udviklingen i perioden 1976-81 er det oplagt, at det offentliges omfordelende rolle, hvad angår de direkte skatter og indkomstoverførslerne, 
er blevet større i perioden 1984-1988. I perioden 1976-81 blev den omfordelende funktion mindre først og fremmest på grund af, at skatterne i højere grad blev betalt af de laveste indkomstgrupper (Hansen, 1985). I perioden 1984-88 er den omfordelende funktion blevet storre, fordi indkomstoverforslerne i højere og højere grad tilfalder de laveste indkomstgrupper.

Med denne udvikling for en væsentlig del af den offentlige sektors udgifts- og indtægtsposter kan man selvfølgelig godt, som det blev omtalt $i$ indledningen, karakterisere den offentlige sektor som i højere grad et service- og tryghedssystem end et omfordelingssystem (Forum for industriel udvikling, 1990). Imidlertid kan det konstateres, at omfordelingen via det offentlige er blevet større i 1980'erne. Spørgsmålet er derfor, om man kan adskille service- og tryghedsfunktionen fra omfordelingsfunktionen. Eller om det ikke snarere er sådan, at det tryghedssystem, som er opbygget med et differentieret net af indkomstoverførsler, netop viser sin omfordelingsfunktion $\mathrm{i}$ perioder med voksende sociale problemer.

\section{Litteratur}

Albæk, Erik og Peter Munk Christiansen (1989). „Velbjærgsstaten*, GRUS, nr. 28, pp. 71-84.

Budgetdepartementet (1990). Udgiftsanalyser. De offentlige udgifter, vakst og fordeling, København: Budgetdepartementet.

Finansministeriet (1985). Finansredegerelse 1986, København: Finansministeriet.

Forum for industriel udvikling (1990). Den offentlige sektors rolle i 90 'ernes samfund, København.

Hansen, Finn Kenneth (1981). Forbrugsmuligheder og omfordelingen over den offentlige sektor, Arbejdsnotat nr. 17, København: Lavindkomstkomissionens sekretariat.

Hansen, Finn Kenneth (1985). Fordelingspolitikken og dens virkninger, København: Socialforskningsinstituttet, publ. 137.

Hansen, Finn Kenneth (1990a). Bornefamiliernes økonomi, København: Socialforskningsinstituttet.

Hansen, Finn Kenneth (1990b). "Fordelingspolitikken og fordelingsanalyser «, Samfundsokono$m e n$, nr. 6, pp. 11-15.

Knudsen, Rita (1987). Sociale kontantydelser 1976-1987, København: Socialforskningsinstituttet, publ. nr. 172.

Liebetrau, Henrik (1983). Dansk socialpolitik 1974-82. Socialistiske økonomers skriftsserie, nr. 8, København.

Social rapport (1989 og 1990). Social rapport nr. 1, 1989 og nr. 2, 1990. Udgivet af Center for Alternativ samfundsanalyse.

Sørensen, Rewald Schmidt (1989). Udviklingen iden personlige indkomstfordeling i 1900-tallet, København: Afhandling ved det statsvidenskabelige kandidatstudium, Økonomisk Institut. 
er blevet større i perioden 1984-1988. I perioden 1976-81 blev den omfordelende funktion mindre først og fremmest på grund af, at skatterne i højere grad blev betalt af de laveste indkomstgrupper (Hansen, 1985). I perioden 1984-88 er den omfordelende funktion blevet storre, fordi indkomstoverforslerne i højere og højere grad tilfalder de laveste indkomstgrupper.

Med denne udvikling for en væsentlig del af den offentlige sektors udgifts- og indtægtsposter kan man selvfølgelig godt, som det blev omtalt $i$ indledningen, karakterisere den offentlige sektor som i højere grad et service- og tryghedssystem end et omfordelingssystem (Forum for industriel udvikling, 1990). Imidlertid kan det konstateres, at omfordelingen via det offentlige er blevet større i 1980'erne. Spørgsmålet er derfor, om man kan adskille service- og tryghedsfunktionen fra omfordelingsfunktionen. Eller om det ikke snarere er sådan, at det tryghedssystem, som er opbygget med et differentieret net af indkomstoverførsler, netop viser sin omfordelingsfunktion $\mathrm{i}$ perioder med voksende sociale problemer.

\section{Litteratur}

Albæk, Erik og Peter Munk Christiansen (1989). „Velbjærgsstaten*, GRUS, nr. 28, pp. 71-84.

Budgetdepartementet (1990). Udgiftsanalyser. De offentlige udgifter, vakst og fordeling, København: Budgetdepartementet.

Finansministeriet (1985). Finansredegerelse 1986, København: Finansministeriet.

Forum for industriel udvikling (1990). Den offentlige sektors rolle i 90 'ernes samfund, København.

Hansen, Finn Kenneth (1981). Forbrugsmuligheder og omfordelingen over den offentlige sektor, Arbejdsnotat nr. 17, København: Lavindkomstkomissionens sekretariat.

Hansen, Finn Kenneth (1985). Fordelingspolitikken og dens virkninger, København: Socialforskningsinstituttet, publ. 137.

Hansen, Finn Kenneth (1990a). Bornefamiliernes økonomi, København: Socialforskningsinstituttet.

Hansen, Finn Kenneth (1990b). "Fordelingspolitikken og fordelingsanalyser «, Samfundsokono$m e n$, nr. 6, pp. 11-15.

Knudsen, Rita (1987). Sociale kontantydelser 1976-1987, København: Socialforskningsinstituttet, publ. nr. 172.

Liebetrau, Henrik (1983). Dansk socialpolitik 1974-82. Socialistiske økonomers skriftsserie, nr. 8, København.

Social rapport (1989 og 1990). Social rapport nr. 1, 1989 og nr. 2, 1990. Udgivet af Center for Alternativ samfundsanalyse.

Sørensen, Rewald Schmidt (1989). Udviklingen iden personlige indkomstfordeling i 1900-tallet, København: Afhandling ved det statsvidenskabelige kandidatstudium, Økonomisk Institut. 